\title{
RELIGIOUS EXPRESSION OF HIJRAH CELEBRITIES: ACCOMMODATING PROTEST AND THE POLITICAL ECONOMY OF PUBLIC PIETY
}

\author{
Afrida Arinal Muna ${ }^{1}$ \\ ${ }^{1}$ State Islamic University of Sunan Kalijaga, Yogyakarta, Indonesia, e-mail : afridaarinal@gmail.com

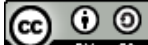 \\ (C)2020 by the authors. Submitted for possible open access publication under the terms and conditions of the Creative Commons \\ Attribution-ShareAlike 4.0 International License-(CC-BY-SA) (https://creativecommons.org/licenses/by-sa/4.0/) \\ doi DOI http://dx.doi.org/10.30983/islam realitas.v6i1.3154 \\ \begin{tabular}{l|l|l} 
Submission : 15 March 2020 & Revised : 6 June 2020 & Published : 4 July 2020
\end{tabular}

\begin{abstract}
This paper explores the motivations behind Indonesian celebrities who undertake hijrah in Indonesia's digital era. Hijrah activities and campaigns have recently been led by several celebrities who invite Muslims to become better practitioners of Islam, usually by promoting religious teachings on digital media. This study uses qualitative research methods and analysis of data from media, especially social media. I argue that celebrities who undertake bijrah not only want to exhibit their new-found religious identity. They also engage in a form of "accommodating protest." That is to say, they try to rally against the negative stigmas that are attached to celebrities who adopt a more religious lifestyle and. They want to show that they will still be popular and can thrive as celebrities despite wearing more modest clothing such as the headscarf (bijab). There is also a political and economic strategy behind an artist's decision to undertake hijrah, as it opens doors to contracts from the so-called halal industry. This is consonant with the recent trends of massive consumerism on the part of the Muslim middle class, which is believed to be primary actors of Indonesia's economic development in the $21^{\text {st }}$ century so far.
\end{abstract} \\ Abstract
}

Keywords: Hijrah celebrity; Digital era; Accomodating; Protest

\begin{abstract}
Abstrak
Makalah ini ingin mengkaji apa motif di balik fenomena selebritis yang hijrah di Indonesia. Aktivitas dan kampanye bijrah sangat masif dilakukan beberapa artis yang mengajak. kaum Muslim untuk menjadi pribadi yang lebih baik. dengan menjalankan ajaran agama yang disuarakan di media digital. Dengan menggunakan metode penelitian kualitatif dan analsis terbadap data media terutama media sosial, ditemukan babwa motif selebriti yang melakukan bijrah sebenarnya tidak hanya ingin menunjukkan ekspresi keberagamaan barunya dengan menunjukekan kesalehannya terbadap publik, tetapi juga sebagai sebuah bentuk. 'accomodating protest' bahwa sebelum mereka memutuskan untuk. hijrah ada sejenis bully-an yaitu munculnya stigma-stigma ketakutan menurunnya citra mereka di hadapan publik. ketika seorang artis melakukan bijrah dengan style bijab barunya. Tetapi justru ada semacam perlawanan yang ingin ditunjukekan oleh para selebriti kepada masyarakat bahwa mereka tetap bisa eksis walaupun memakai jilbab dan juga ada strategi politik ekonomi yang dimainkan oleh artis-artis hijrah tersebut dengan membuat inovasi-inovasi industri halal, tren hijab yang sangat populer.
\end{abstract}

Kata Kunci: Selebriti Hijrah; Era digital; Akomodasi; Protes

\section{Background}

In Indonesia, Islamic discourse grown considerably after the Reformation movement of 1999 and the rise of globalization. Globalization in particular has narrowed time and space not only theoretically, but also the practically. ${ }^{1}$ From this, various kinds resistances against the global cultural hegemony have emerged in Indonesia. The kind of resistance discussed in this paper is religiously motivated and is known by the term bijrah. The bijrah exerts a strong influence over the urban middle class, who are frustrated and thirsty for a grounded and pious religious identity. This middle-class group is currently at the center of social change and economic development in Indonesia. The so-called Muslim middle class in Indonesia emerged in the wake of the 1979 Iranian revolution. ${ }^{2}$ This event led to a growth of Islamic political and identity movements in the Muslim world. Indonesian Muslim women
${ }^{1}$ David Harvey, The Condition of Posmodernity (Cambridge: Basil Blackwell, 1997), p. 260.
${ }^{2}$ Moeflich Hasbullah, 'Teori Habitus Bordieu dan Kehadiran Kelas Menengah Muslim Indonesia', Khazanah, 21.1 (2007), 5. 
began to wear the hijab (headscarf), following the culture of Muslim women of Iran and other Middle Eastern countries. Even a number of artists also began embracing bijab culture. The emerging Muslim middle class began to develop a common identity formed by social codes related to loyalty, commitment, attributions, and affiliations that exhibit their religious, linguistic, and cultural preferences. ${ }^{3}$

This new social phenomenon among the Indonesian middle class can be prominently seen in the Mark Plus Conference 2012 in Jakarta. The founder of this event stated that the middle class in 2012 has experienced a very large boom, which has many implications for market behavior. The rise of the middle class is directly proportional to the demand for lifestyle products, beauty products, health services, tourism, and transportation ${ }^{4}$. This phenomenon is also influenced by symbolic interactions, because human behavior is the product of their interpretation of the world around them. ${ }^{5}$ Indonesia's economy is driven by a combination of middle class and urban society. This phenomenon is displays how celebrities desire to show their participation in the global community by performing trendy cultural practices in Indonesia.

Looking at Bourdieu's framework of his habitus theory, we can see that the Indonesian community during the 1980s and 1990s displayed an unmistakable middle-class culture, especially among the urban community. The five social phenomena that are indicative of this trend are: the use of the veil as an affirmation of class identity; the emergence of modern Islamic songs of the popular band Bimbo; the establishment of the Indonesian Muslim
Intellectuals Association (ICMI); the publication of Islamic media; and the hosting of elite Islamic conferences in prestigious places and starred hotels. These social phenomena were not only a form of increased religious expression or a symptom of the revival of Islamic revival in the 1980-1990s but is part of what Bourdieu calls as cultural reproduction of social investment that is continually carried out. In the case of Indonesia, this cultural reproduction confirms the formation of a new Muslim middle-class identity ${ }^{6}$. The discourse of bijrah among the urban Muslim middle class is part of this social trend.

The hijrah campaign is a massive religious movement that invites Muslims to become better practitioners of Islam. Undertaking hijrah is often a very public affair, usually exhibited on digital media, including social media platforms. On the popular digital news platform detiknews and on Instagram, the hashtag \#hijrah has more than 1.7 million posts. The bijrah account on Facebook has also been followed by more than 300 thousand accounts. ${ }^{7}$ This phenomenon is also popular among Indonesian celebrities, given the fact that this phenomenon is highly popular among the middle to upper classes, who have the means to consume trending issues trending on social media. The trend of bijrah also influenced a series of celebrities who decided to undertake hijrah, but with a different approach.

The existence of a middle-class Muslims living in urban areas cannot be separated from the growth of religiosity and spirituality among this group of people. ${ }^{8}$ This can be seen from the rise of bijrah trends. In this digital age, the various digital platforms have been spaces of
${ }^{3}$ Rao Aparno, 'The Many Sources of Identity: An Example of Changing Affiliations in Rural Jammu dan Kashmir', 22.1 (1999), 56.

${ }^{4}$ Kris Moerwanto, 'Bangkitnya Kelas Menengah dan Perubahan Perilaku Pasar', Jawa Pos (Jakarta, 2011).

${ }^{5}$ Ade Nur Istiani, 'Kontruksi Makna Hijab Fashion Bagi Moeslem Fashion Blogger', Jurnal Kajian Komunikasi, 3.1 (2015), 51.
'Pierre Bourdieu, Reproduction in Education (London and Beverly Hills: Sage, 1977), p. 71-80.

${ }^{7}$ Abdul Hair, 'Fenomena Hijrah di Kalangan Anak Muda', Detik New 7 (Surabaya, 2018).

${ }^{8}$ Rofhani, 'Budaya Urban Muslim Kelas Menengah', Teosofi, 3. 1 (2013), 200. 
contestation where celebrities try to increase their fame through exhibiting their bijrah lifestyle. This has been viewed as part of a wider trend of increasing exclusivism in religious practice. The celebrities who performed hijrab is part of a new community that tries to maintain their new identity in the public sphere.?

The present study attempts to understand the motives behind the celebrities who undertake hijrah. It argues that they are motivated not only to acquire the status of a pious person in the eyes of the public, but also to carry out what Macleod, in his study on veiled women in Cairo, describes as "accommodating protest." Furthermore, there are political economic benefits motivating the hijrah celebrity.

\section{The Label of Public Piety in the Hijrah Celebrities' Religious Expression}

Hijrah is etymologically derived from an Arabic word which means "to leave," "to keep away from," and "to move." Hijrah is classified into two types: hijrah makaniyah (moving from one place to another) and bijrah ma'nawiyah (changing yourself better to get closer to Allah and to get pleasure from Allah). Hijrah ma'nawiyah is further divided into four categories; hijrah i'tiqadiyah (bijrah of conviction), bijrah fikriyah (bijrah of thought), hijrah shu'uriyah (changing of a person based on his appearance) ,and hijrah sulukiyah (bijrah of behavior or personality $)^{10}$.

Hijrah during the time of the Prophet had five distinct meanings: hijrah as a strategy in the struggle of the Prophet; hijrah as an affirmation of Muslim identity, migrating to build a new civilization; hijrah as a concept of unity; and bijrah as a concept of an egalitarian society. ${ }^{11}$ In addition, hijrah can also be contextualized as a renewal both in the fields of education, politics, ${ }^{12}$ and other meanings relating to religious reformation. In the latter case, the term bijrah is used with da'wah (Islamic propagation). ${ }^{13}$ Despite the richness of the meaning of this term, many urban Muslims restrict their understanding of hijrah to the hijab or religious headscarf. As a result, hijrah is considered as a public symbol of someone's piety.

As mentioned above, the hijrah campaign is increasingly being echoed in social media platforms. Celebrities are particularly skilled in making use of these public platforms. These celebrities include Indah Dwi Pertiwi, Laudya Cintia Bella, Alyssa Soebandono, Melly Goeslow, Dewi Sandra, Cut Meyriska, Zaskia Adya Mecca, and others. In deciding to undertake bijrah, these celebrities are able to use their new identities to show their piety while profiting economically from the exposure. More importantly, they are able to launch an "accommodating protest" to the public, as if to declare that that they can still exist in the celebrity world and remain relevant despite wearing the hijab. The hijrah celebrity also consume popular Islamic causes associated with the emergence of the post-Islamist politics. Roy argues that that post-Islamism is a part of privatization of Islamization, which is the process of forming a personal but eminently social piety. ${ }^{14}$ Asef Bayat also argues that postIslamism, which was originally a transformation in Islamization processes to the formation of an Islamic State, is now directed towards the
${ }^{9}$ Rahmi Nur Fitri and Indah Rama Jayanti, 'Fenomena Seleb Hijrah: Tendensi Eksklusivisme dan Kemunculan Kelompok Sosial Baru', Mubarrik: Jurnal Dakwah dan Sosial, 3.1 (2020), 1.

${ }^{10}$ Ahzami S.J, Hijrah dalam Pandangan Al-Qur'an (Jakarta: Gema Insani, 2012), p. 65-68.
${ }^{11}$ Muhammad Taufik Ismail and Zaenal Abidin, 'Kontekstualisasi Hijrah Sebagai Titik Tolak Pembaharuan Pendidikan', Subuf, 29, 2.1 (2017), 56-57. 12 Ismail and Abidin.

${ }^{13}$ Aswadi, 'Refomulasi Epistemologi Hijrah dalam Dakwah', Islamica, 5. 2 (2011), 339-53.

${ }^{14}$ Oliver Roy, The Failure of Political Islam (Cambridge: Harvard University Press, 2003), p. 36. 
formation of an attitude of social piety both individually and collectively ${ }^{15}$.

The bijrah trend reveals the impact of modernity on urban communities who are frustrated and thirsty for piety. They consider the veil as a symbol of piety. Posetti J. N. also argues that the bijab is one of the more prominent symbols of bijrah-piety. ${ }^{16}$ The hijab is the celebrities' response to modernity and the rise of global culture that they regard as alienating, inauthentic and not in accordance with Islamic teachings.

Clothing has a communicative function, which is a form of artifactual communication within the scope of nonverbal communication. ${ }^{17}$ Clothing conveys meaningful messages in the same way that language conveys a message. In Chaney's language, "clothing is self-representation is the initial footing for interacting with the formation of impressions, statements of identity and even ideology."18 Therefore, we can see why the Muslim community gave the label of piety to hijrah celebrities who express their new-found religiosity by dressing more modestly.

As the Muslim middle-class continue to grow in Indonesia, the public has shown a their bijrah status. These celebrities, in turn, become public figures. The parameters of piety proposed by Pepinsky, Liddle and Mujani in the Piety and Public Opinion: Understanding Indonesian Islam are ritual, orientation and behavior. ${ }^{19}$ Rituals are related to the performance of the pillars of Islam; orientation is related to an individual Muslim's beliefs about his or her growing appreciation for celebrities who exhibit

relationship with the Islamic faith; while behavior includes all practices reflecting religious faith. ${ }^{20}$ Based on these parameters, the label of piety can be given to celebrities' exhibition of their bijrah status because they perform rituals, have a religious orientation, and carry out certain behaviors that demonstrate their Islamic identity.

The rituals of social piety as one of the rituals of Muslim middle-class identity are divided into four forms: how intensely worship must be carried out; how they carry out God's commands; public celebrations of religious rituals; and interaction between socioeconomic values and religious values. ${ }^{21}$ Looking at these four indicators, Wasisto suggests that the ritual of middle-class identity is divided into two things, namely the need for spiritual satisfaction and the need for existential contentment. ${ }^{22}$ The need for spirituality can be seen in how people carry out worship, obey God's commands, and others. Celebrities who undertake hijrah focus on these aspects as symbols of their new-found spirituality. Second, the need for existential contentment is indicated by the consumption of commodities that are considered religious and are considered as representing authentic Islamic identity. Artists do undertake hijrah by wearing headscarves and modest clothing in general try to show that they are authentic Muslims, are obedient to God's commands, and avoid His prohibitions.

\section{Hijrah Celebrity as a Form of "Accommodating Protest"}

The bijab as a new identity-marker of a celebrity who undergoes hijrah is a meaningful

${ }^{15}$ Asef Bayat, Making Islam Democratic: Social Movement and The Post-Islamist Turn (Stanford: Standford University Press, 2007), p. 9-10.

${ }^{16}$ Posetti, J.N, 'Media Representations of the Hijab', Journalism in Murlicultural Australia, Case Study 1, (2006), 1.

${ }^{17}$ Gerungan, Psikologi Sosial (Bandung: Eresco, 1996), p. 67.

${ }^{18}$ David Chaney, Lifestyles: Sebuah Pengantar Komprehensif (Bandung: Jalasutra, 1996), p. 213.
${ }^{19}$ Thomas B. Pepinsky, R. William Liddle, and Saiful Mujani, Piety and Public Opinion: Understanding Indonesian Islam (New York: Oxford University Press, 2018), p. 62.

${ }^{20}$ Thomas B. Pepinsky, R. William Liddle, and Saiful Mujani, Piety and Public Opinion: Understanding Indonesian Islam (New York: Oxford University Press, 2018), p. 62.

${ }^{21}$ Riesebordt, Pious Passion (Berkeley: University of California Press, 1993), p. 195.

${ }^{22}$ Wasisto Raharjo Jati, 'Kesalehan Sosial Sebagai Ritual Kelas Menengah', Jurnal Kebudayaan Islam, 13. 2 (2015), 346. 
phenomenon. According to Geertz, this phenomenon has become a belief in life. The bijab is considered to be part of the Islamic tradition. In addition, the veil also functions as a sign that conveys social and cultural messages. ${ }^{23}$ Muslim women in Malaysia, for instance, were able to slowly deflect the widelyheld perception that women wearing the bijab are oppressed. ${ }^{24}$ Indeed, the veil as a potent symbol in Muslim societies has experienced significant transformations of meaning. The bijab is not only a symbol of religious identity, but is also meaningful in cultural, social, political, economic, and fashion domains. When the veil is worn by a celebrity, it changes into a very complex social phenomenon.

The physical appearance of a bijab-clad hijrah celebrity is fraught with religious values, social habits, political and cultural imaginations, etc. By wearing Muslim clothes, people become part of a group. A Muslim woman who wears the bijab is seen as a manifestation of Islamic teachings. Wearing hijab is an example of an artifactual message. The celebrity who undertake bijrah has many motivations. ${ }^{25}$ Alfred Schutz divides motivations into "so"-motives and "because"-motivations. The motive is related to face-to-face interaction. The "so" motive is a purpose intended as an intention, plan, hope, interest, and so on. This motive has a future orientation. The "because" motive refers to past experiences of the celebrity and is embedded in his or her knowledge. Therefore, this motive is oriented to the past. During the face-to-face interaction process, there is an exchange of motives among the involved actors. A new individual can change his actions according to the actions of others. The hijrah celebrity would have a number of motives other than to show their new identity. One important motivation is the desire to enact some form of "accommodating protest" as a response to the surrounding environment.

This study departs from Arlene Elowe Macleod's study of middle-lower-class Cairene women, who started a form of protest against the ruling authority. This protest consists in the escaping from the patriarchal social structure by occupying public positions traditionally held by males; they do this by wearing the veil, which is usually seen as a symbol of confinement in Muslim patriarchal societies. ${ }^{26}$ El-Guindi's study stated that clothing is often used as a symbol of resistance and liberation, as well as political movements. When the mullah movement began to intensify in Iran in the 1970s and reached its peak in 1979, Khomeini succeeded in overthrowing Reza Pahlavi, which was known as an accomplice of Western imperialism in the Middle East. Khomeini became a symbol of Islamic victory over Western puppets. Symbols of Khomeini's revolution, such as photographs of Khomeini himself and the Black Veil community became a trend among young generations of Muslims throughout the world. Clothing identity (i.e., the veil) is considered to be a symbol of victory. ${ }^{27}$ In contrast to the case in Iran, young women in Europe used the full face-cover (niqab) as a tool for resistance; whereas in America the niqab was rejected. ${ }^{28}$

Hijrah performed by celebrities is also a kind of public protest. As seen in various interviews, celebrities underwent bijrah not only
${ }^{23}$ Clifford Geertz, Kebudayaan dan Agama (Yogyakarta: Kanisius, 1992), p. 32.

${ }^{24}$ Nurzihan Hassim, 'Hijab and the Malay-Muslim Woman in Media', Procedia Social and Behavioral Sciences, 155. 1 (2014), 428-33.

25 Gerungan.

${ }^{26}$ Arlene Elow Macleod, Accomodating Protest: Working Women, the New Veiling and Change in Cairo (New York: Columbia University Press, 1991), p. 20.
${ }^{27}$ Fedwa El-Guindi, Jilbab Antara Kesalehan, Kesopanan, Dan Perlawanan (Jakarta: Serambi Ilmu Semesta, 2004), p. 268-70.

${ }^{28}$ Faegheh Shirazi and Smeeta Mishra, Young Muslim Women on the Face Veil (Niqab) : A Tool of Resistance in Europe but Rejected in the United States', International Journal of Cultural Studies, 13. 1 (2010), 43-62; Pamela Nunez Basante, 'Beyond the Veil: Media Prejudice Towards the Use of the Hijab', International Journal for Intersectional Feminist Studies, 5.1-2 (2019), 13-21. 
to show their new-found religiosity, but also enact a certain protest (i.e., an "accommodating protest"). They expressed that before their hijrah, many people tried to detract them from being more religious, because of the gear that their image and popularity will decline if they begin to wear the hijab. Instead, they want to show that they can still thrive as celebrities and public figures even when they wear more modest clothing. This is what is meant by "accommodating protest."

Some celebrities who perform bijrah, such as Laudya Cintya Bella, Dewi Sandra, Citra Kirana, Cut Meyrizk, do not necessarily wear long robes or the "unfashionable" wide bijab. Rather they wear a modest style that they deem to be syar'i (Arabic: shar'i, meaning "in accordance with Islamic law") while being stylish at the same time. They are aware of how the rules of syar'i clothing can still accommodate the trends in fashion. This is caused by the fact that many celebrity and artistic environment is not completely supportive of "unfashionable" modest female clothing. As a result, they can be seen as conducting an "accommodating protest" against religious rules and community stigma. They accommodate religious teachings regarding modesty in dressing, but they also do not want to lose their image and popularity in public. Instead, they want to fight the negative stigma attached to their new identity by wearing the bijab fashionably. In fact, they are able to become more popular, given that the bijrah trend is on the rise among Indonesian urban communities and consumerism has become a fact of urban life. Given the rise of Islamic or halal industries in food products, tourism, and others, there is no shortage of brands they can represent and monetize as celebrities .

Hijrah celebrities realize that while the headscarf was initially seen as a barrier for women to flourish in the public sphere, now it has become a trend that is favored by many people. However, many people argue that the headscarf is a traditional practice that has no relevance in contemporary society. Others hold that it is a clear obligation for Muslim women.

Although nowadays the headscarf is not a barrier for a woman to appear in the public sphere, it still limits women's participation because of the expectations imposed by the patriarchal society. The mindset of the Indonesia people is influenced by religious understanding, and patriarchal culture is still strong. In this system, women are always at a subordinate position at best complementary to men. However, this patriarchal culture began to erode, because of the increasing awareness of women's rights. In the aftermath of the Iranian Islamic Revolution in 1979, Muslim self-esteem rose in the eyes of the world, especially with respect to the Western world. ${ }^{29}$ One of the major cultural shifts that was born out of this event is the phenomenon of veiling among women, which as continued unabated every since. This social trend has made it easier for celebrities to also beign wearing the hijab.

Modernization is often considered as something that undermines religious values; however, the opposite effect tends to happen, namely that the trend of hijrah seems to gather pace despite of modernity. In the hands of celebrities in particular, the bijab became less a symbol of old-fashion clothing and more of a fashion statement during the global era. They managed to inspire young people in engaging with their religious lifestyle. They appear in public in their new-found identity, which was then imitated by young women.

\section{The Political Economy of Hijrah Celebrity in the Digital Age}

The bijrab celebrity has a new arena in this digital age to display their new identity. Their new role is not only to exhibit religious piety. They also benefit economically and at times politically. These celebrities are savvy users of

${ }^{29}$ Hasbullah. 
social media, which they use to promote their products. In the early 20th century, capitalist culture and the emergence of a consumerist society needed the continued supply of consumers. From this a new role to promote that industry was formed..$^{30}$ Laura Nistor called the bijab is promoted not only as a religious symbol, but also as a fashion phenomenon. ${ }^{31}$ Thus, in this context, hijrah celebrities operate as owners of capital who promote their products along with their new religious identity. They also use their new identity to receive endorsements from so-called "Islamic" or halal products..

The term political economy is offered by Vincent Mosco referring to (political) power relationships from existing economic sources. This relationship is one of mutual benefit between sources of production, distribution, and consumption. The ruler that is referred to by Mosco as the "de facto ruler" is the person who is deemed able to move an individual or group of people even though do not hold de jure executive, legislative and judicial powers. ${ }^{32}$ Hijrah celebrities seems to have this kind of $d e$ facto power, because they are able to influence society by their new-found identities.

The popularity of hijrah celebrities and the mushrooming of the latest fashion and bijab products, as well as the product endorsements targeted to the Muslim middle class are interesting topics of study. Now celebrities engage not only about religious ideology, but they also play an important role in the economy and politics. This is a new site of contestation. Clifford Geertz has shown how ideology is a cultural system. If this is accepted, then any thought that is expressed cannot be separated from the condition and situation of the community. Departing from this, Geertz explores ideology through two approaches, one of which is the theory of interest (the interest theory), which can be understood as a weapon to maintain an industry's presence in society, whether the "balal' industry or otherwise. ${ }^{33}$

In the theory of interests, ideological statements are made pulic to gain advantage and power. Because hijrah has become a trend, celebrities also use the opportunity to increase their popularity and promote products that are related to religious symbols such as Muslim clothes, the robe, headscarf, halal food, halal tourism, and others. They use the media to influence women to follow their identities and to promote their product brands. As stated by Latif and Fatin, the media has a role in commercializing the hijab in this modern era. ${ }^{34}$

Many companies also often use celebrities to persuade consumers to buy the products they buy. Accordig to Shimp said, all forms of marketing delivery and promotion are ultimately intended to persuade consumers to do things that benefit marketers. ${ }^{35}$ The companies of these "Islamic" and "balal" products chose new celebrities to endorse their products because they have a new image that can increase the sales of their products. For example, Dewi Sandra endorses the Ampo bijab and is an ambassador for Wardah products, which is advertised as halal cosmetics. Laudya Cintia Bella promotes her own product, a bijab called lbylbc.

The social structure shows the objective relationship of the position held by an actor in a given arena. ${ }^{36}$ The actor in this case is bijrah
${ }^{30}$ Laughey, D., Media Studies:Theories and Approaches (London: Oldcastle Book, 2010), p. 117.

${ }^{31}$ Laura Nistor, 'Hijab (Istas) as Fashion Phenomenon', Acta Univ, Sapientiae, Social Analysis, 7. 1 (2017), 59.

32Willam John, The Political Economy of Communication, 2nd edn (London: Sage Publication, 2009), p. 127.

${ }_{33}$ Clifford Geertz, The Interpretation of Culture (New York: Basic Book, 1973), p. 201-2.
${ }^{34}$ Zulkifli Abd. Latiff and Fatin Nur Sofia Alam, 'The Roles of Media in Influencing Women Wearing Hijab:An Analysis', Journal of Image and Graphics, 1.1 (2013), 50.

${ }^{35}$ Torence A Shimp, Promotion Management and Marketing Communications (Orlando: The Dryden Press, 1990), p.130.

${ }^{36}$ Bourdieu. 
celebrities. These celebrities compete for money, prestige, and power. Religious power is demonstrated through the authority they may have in influencing the practices and views of ordinary people through the mechanism of relative absolution and legitimacy. Bourdieu holds that religion is the key in the production of a structure. ${ }^{37}$ The designers, traders, including celebrities have positions as religious specialists who translate the views of religious leaders into cultural products such as headscarves, Muslim clothes, halal travel, halal food, and other halal products.

According to Shimp, there are several factors that are considered in the selection of celebrities to become brand ambassadors. These include the celebrity's credibility and compatibility with the audience and the brand and the perceived attractiveness of said celebrity. In other words, in order to determine which celebrity should be selected as the endorser of a product, that celebrity must already have some sort of relationship with the public and the product offered. When companies use endorsers that are attractive and are compatible with the audience and the brand, brand awareness can be achieved effectively. ${ }^{38}$

Digital media as a medium for global social interaction through social media platforms, such as YouTube and others, are a means for cultural reproduction that are carried out continuously by individuals in various social classes. The media as a tool for celebrity contestation requires certain expertise and capital, which is referred to as capital by Bourdieu. ${ }^{39}$ Cashmore has analyzed the relationship between celebrities and commodification as well as consumers and examined the use of new media. ${ }^{40}$ The analysis shows that celebrity culture goes hand in hand with commodification. The commodification in question is when a public figure is converted into a trade commodity that is exchanged in the market.

Within the current development of capitalism, the development of the Muslim market is increasing. Thus, there is a law of supply and demand side markets. The supply of industrial machinery not only offers a potential object of desire for someone to consume, but also actively affects the imagination and tastes of consumers. These tastes are always part of the current trends in lifestyle among the middleclass. On the other hand, the demand position is seen by the increasing number of the Muslim middle class who can create demand in accordance with the current lifestyle trends. ${ }^{41}$ Commodification is considered as one way to see changes in goods or services to be used to push sales through the political economy approach of the media. ${ }^{42}$ This can be seen from celebrities who transform themselves from being "un-Islamic" to "Islamic." The celebrity will no doubt get the attention of the media and the public. Thishas the effect of increasing selling power because the Muslim middle class in Indonesia is increasing.

\section{Conclusion}

The bijrab phenomenon of moving to has become a trend among urban communities, including celebrities. This doctrine of hijrah reflects the frustrations of the urban middle class who are thirsty for an identity grounded in religious piety. This middle-class group is

${ }^{41}$ Abdur Rozaki, 'Komodifikasi Islam: Kesalehan dan Pergulatan di Ruang Publik', Jurnal Dakwah, 2. 4 (2013), 201-2. Kirana Nur Lyansari, 'Hijrah Celebrity: Creating New Religiosities, Branding Economics of Lifestyle in the Age of Muslim Mass Consumption', Analisis: Jurnal Studi Keislaman, 18. 2 (2018), 211-32.

42 Indah Pratiwi Manggaga, 'Komodifikasi Konten Televisi dalam Perspektif Ekonomi Politik Media', Jurnal Tabligh, 19. 2 (2018), 259. 
currently at the center of social change and is placed at a strategic place in Indonesia's economic and cultural development. The emergence of middle-class Muslims in Indonesia was influenced by the 1979 Iranian revolution. This event changed the relationship between Muslim societies and the world. In Indonesia, this event led to Islamic patterns of consumption that is specifically associated with the emergence of the post-Islamism phenomenon. They began to wear the veil to follow the culture of Muslim women in Iran and other Middle Eastern countries. This discourse is now known as the bijrah discourse, which is closely related to the wearing of the bijab in such a way as to satisfy both the requirements of religion as well as fashion.

Celebrities practicing bijrah are not something free from motives, especially when the discourse of hijrah is faced with the growing diversity of Indonesian society. I conclude that celebrities who undertake hijrah not only want to exhibit their new-found identity to the public for public acknowledgement of their status as good and pious Muslim women. They also perform a kind of accommodating protest. That is to say, they want to fight off the negative stigmas that arise from their decision to wear the bijab, most notably that they will not be able to thrive as celebrities while wearing more modest clothing. In fact, given the growth of the Muslim middle class, their stock among the public seems to have risen. The phenomenon of bijrah will only increase as a social and cultural trend in contemporary Indonesia.

Furthermore, bijrab celebrities have a new public platform in this digital age to display their new identity. In this regard, their motivations for public display is intertwined with economic and political motivations. As celebrities, they compete for advertisements slots and ambassador roles in companies labeled as Islamic or halal. A number of them have become entrepreneurs themselves, selling personal products such as headscarves, robes, halal travel services, halal food and others. Thus, they are brand ambassadors for their own brands.

\section{References}

\section{Books}

Ahzami S.J, Hijrah dalam Pandangan Al-Qur'an (Jakarta: Gema Insani, 2012)

Arlene Elow Macleod, Accomodating Protest: Working Women, the New Veiling and Change in Cairo (New York: Columbia University Press, 1991)

Bayat, Asef, Making Islam Democratic: Social Movement and The Post-Islamist Turn (Stanford: Standford University Press, 2007)

Bourdieu P, Distinction: A Social Critique of the Judgement of Taste (Taylor \& Francis, 2013)

--------, Reproduction in Education (London and Beverly Hills: Sage, 1977)

Cashmore, Celebrity/Culture (New York: Routledge, 2006)

Chaney, David, Lifestyles: Sebuah Pengantar Komprehensif (Bandung: Jalasutra, 1996)

El-Guindi, Fedwa, Jilbab Antara Kesalehan, Kesopanan, Dan Perlawanan (Jakarta: Serambi Ilmu Semesta, 2004)

Geertz, Clifford, Kebudayaan dan Agama (Yogyakarta: Kanisius, 1992)

Geertz, Clifford, The Interpretation of Culture (New York: Basic Book, 1973)

Gerungan, Psikologi Sosial (Bandung: Eresco, 1996)

Harvey, David, The Condition of Posmodernity (Cambridge: Basil Blackwell, 1997)

John, Willam, The Political Economy of Communication, 2nd edn (London: Sage Publication, 2009)

Laughey, D, Media Studies:Theories and Approaches (London: Oldcastle Book, 2010).

Pepinsky, Thomas B., R. William Liddle, and Saiful Mujani, Piety and Public Opinion: Understanding Indonesian Islam (New York: Oxford University Press, 2018) 
Riesebordt, Pious Passion (Berkeley: University of California Press, 1993)

Roy, Oliver, The Failure of Political Islam (Cambridge: Harvard University Press, 2003)

Shimp, Torence A, Perikanan Promosi, Aspek Tambahan Komunikasi Pemasaran Terpadu (Jakarta: Erlangga, 2003)

-------, Promotion Management and Marketing Communications (Orlando: The Dryden Press, 1990)

\section{Journals}

Aparno, Rao, 'The Many Sources of Identity: An Example of Changing Affiliations in Rural Jammu dan Kashmir', 22.1 (1999), 56

Aswadi, 'Refomulasi Epistemologi Hijrah dalam Dakwah', Islamica, 5.2 (2011), 339_ 53

Basante, Pamela Nunez, 'Beyond the Veil: Media Prejudice Towards the Use of the Hijab', International Journal for Intersectional Feminist Studies, 5.1-2 (2019), 13-21

Fitri, Rahmi Nur and Indah Rama Jayanti, 'Fenomena Seleb Hijrah: Tendensi Eksklusivisme dan Kemunculan Kelompok Sosial Baru', Mubarrik: Jurnal Dakwah dan Sosial, 3.1 (2020), 1

Hasbullah, Moeflich, 'Teori Habitus Bordieu dan Kehadiran Kelas Menengah Muslim Indonesia', Kharanah, 21.1 (2007), 5

Hassim, Nurzihan, 'Hijab and the MalayMuslim Woman in Media', Procedia Social and Behavioral Sciences, 155.1 (2014), 42833

Ismail, Muhammad Taufik and Zaenal Abidin, 'Kontekstualisasi Hijrah Sebagai Titik Tolak Pembaharuan Pendidikan', Subuf, 29, 2.1 (2017), 56-57

Istiani, Ade Nur, 'Kontruksi Makna Hijab Fashion Bagi Moeslem Fashion Blogger', Jurnal Kajian Komunikasi, 3.1 (2015), 51

Jati, Wasisto Raharjo, 'Kesalehan Sosial Sebagai Ritual Kelas Menengah', Jurnal Kebudayaan Islam, 13. 2 (2015), 346
Latif, Zulkifli Abd. and Fatin Nur Sofia Alam, 'The Roles of Media in Influencing Women Wearing Hijab:An Analysis', Journal of Image and Graphics, 1.1 (2013), 50

Lyansari, Kirana Nur, 'Hijrah Celebrity: Creating New Religiosities, Branding Economics of Lifestyle in the Age of Muslim Mass Consumption', Analisis: Jurnal Studi Keislaman, 18. 2 (2018), 21132

Manggaga, Indah Pratiwi, 'Komodifikasi Konten Televisi dalam Perspektif Ekonomi Politik Media', Jurnal Tabligh, 19. 2 (2018), 259

Nistor, Laura, 'Hijab (Istas) as Fashion Phenomenon', Acta Univ, Sapientiae, Social Analysis, 7. 1 (2017), 59

Posetti, J.N, 'Media Representations of the Hijab', Journalism in Murlicultural Australia, Case Study 1, (2006), 1

Rofhani, 'Budaya Urban Muslim Kelas Menengah', Teosofi, 3.1 (2013), 200

Rozaki, Abdur, 'Komodifikasi Islam: Kesalehan dan Pergulatan di Ruang Publik', Jurnal Dakwah, 2.4 (2013), 201-2

Shirazi, Faegheh and Smeeta Mishra, Young Muslim Women on the Face Veil (Niqab): A Tool of Resistance in Europe but Rejected in the United States', International Journal of Cultural Studies, 13. 1 (2010), 43-62

Yusuf, Muhammad Fahrudin, 'Komodifikasi: Cermin Retak Agama di Televisi:Perspektif Ekonomi Politik Media', Inject: Interdisciplinery Journal of Communication, 1, 1 (2016), 25-42

\section{Others}

Hair, Abdul, 'Fenomena Hijrah di Kalangan Anak Muda', Detik New 7 (Jakarta, 2018)

Moerwanto, Kris, 'Bangkitnya Kelas Menengah dan Perubahan Perilaku Pasar', Jawa Pos (Surabaya, 2011) 